\title{
Adsorption of phenol onto activated carbon from Rhazya stricta: determination of the optimal experimental parameters using factorial design
}

\author{
A. K. Hegazy • N. T. Abdel-Ghani • \\ G. A. El-Chaghaby
}

Received: 10 June 2013/ Accepted: 18 November 2013/Published online: 11 December 2013

(C) The Author(s) 2013. This article is published with open access at Springerlink.com

\begin{abstract}
A novel activated carbon was prepared from Rhazya stricta leaves and was successfully used as an adsorbent for phenol removal from aqueous solution. The prepared activated carbon was characterized by FTIR and SEM analysis. Three factors (namely, temperature, $\mathrm{pH}$ and adsorbent dose) were screened to study their effect on the adsorption of phenol by $R$. stricta activated carbon. A $2^{3}$ full factorial design was employed for optimizing the adsorption process. The removal of phenol by adsorption onto R. stricta carbon reached $85 \%$ at a solution $\mathrm{pH}$ of 3 , an adsorbent dose of $0.5 \mathrm{~g} / \mathrm{l}$ and a temperature of $45^{\circ} \mathrm{C}$. The temperature and adsorbent weight had a positive effect on phenol removal percentage, when both factors were changed from low to high and the opposite is true for the initial solution $\mathrm{pH}$. The results of the main effects showed that the three studied factors significantly affected phenol removal by $R$. stricta carbon with $95 \%$ confidence level. The interaction effects revealed that the interaction between the temperature and $\mathrm{pH}$ had the most significant effect on the removal percentage of phenol by $R$. stricta activated carbon. The present work showed that the carbon
\end{abstract}

\section{A. K. Hegazy}

Department of Botany and Microbiology, College of Science,

King Saud University, Riyadh, Saudi Arabia

\section{A. K. Hegazy}

Department of Botany, Faculty of Science, Cairo University, Giza, Egypt

\section{N. T. Abdel-Ghani}

Chemistry Department, Faculty of Science, Cairo University, Giza, Egypt

G. A. El-Chaghaby $(\square)$

RCFF, Agricultural Research Center, Giza, Egypt

e-mail: ghadiraly@yahoo.com prepared from a low-cost and natural material which is $R$. stricta leaves is a good adsorbent for the removal of phenol from aqueous solution.

Keywords Adsorption - Activated carbon - Phenol . Factorial design $\cdot$ Rhazya stricta

\section{Introduction}

Phenols are among the most common water pollutants (Nayak and Singh 2007), and considered as major toxic pollutant, even at a concentration of as low as $0.1 \mathrm{ppm}$ (Subramanyam and Das 2009). The US Environmental Protection Agency (EPA) regulations call for lowering phenol content in the wastewater to $<1 \mathrm{mg} / \mathrm{l}$ (Hameed and Rahman 2008).

Phenols are introduced into surface water from industrial effluents such as those from the coal tar, gasoline, plastic, rubber proofing, disinfectant, pharmaceutical and steel industries and domestic wastewaters, agricultural runoff and chemical spills (Lin and Juang 2009).

The ingestion of such contaminated water in the human body causes protein degeneration, tissue erosion and paralysis of the central nervous system and also damages the kidney, liver and pancreas (Hameed and Rahman 2008). Ingestion of a small amount of phenol by human beings may cause nausea, vomiting, paralysis, coma, greenish or smoky colored urine and even death from respiratory failure or cardiac arrests. Fatal poisoning may also occur by adsorption of phenol by skin, if a large area of the body is exposed (Mohanty et al. 2005).

The most common methods used for removal of phenol from industrial effluents include stripping, solvent extraction, oxidation, ion exchange, biodegradation and 
adsorption methods (Subramanyam and Das 2009). Out of all these treatment methods, adsorption process is recognized as the most efficient, promising and widely used fundamental approach in wastewater treatment processes, mainly hinging on its simplicity, economically viable, technically feasible and socially acceptable (Foo and Hameed 2010).

In our previous researches, the potential use of different low-cost and eco-friendly adsorbents have been achieved. Recently, Typha domingensis biomass was successfully used as a biosorbent for aluminum (Abdel-Ghani et al. 2009), iron and zinc ions removal from aqueous solution (Hegazy et al. 2011).

Activated carbons are the most versatile and commonly used adsorbents because of their extremely high surface areas, micropore volumes, large adsorption capacities, fast adsorption kinetics and relative ease of regeneration (Tongpoothorn et al. 2011). Carboxylic, carbonylic, lactonic, phenolic, aldehydic and other organic functional groups are located at the edges of hexagonal carbon layer planes and are responsible for surface reactivity of activated carbon (Momcilovic et al. 2011).

Materials that can produce activated carbons from plant origin include wood, peat, lignin, coal, vegetable waste from food processing, coconut shells, nut shells (Poinern et al. 2011). Many previous studies reported successful preparation of activated carbons from various plant biomasses including Euphorbia rigida (Gerçel et al. 2007), Typha orientalis (Zhang et al. 2008), Enteromorpha prolifera ( $\mathrm{Li}$ et al. 2010), Jatropha curcas fruit shell (Tongpoothorn et al. 2011), Zizania latifolia (Huang et al. 2012), etc.

In the present study, Rhazya stricta leaves were used as a precursor material for the preparation of activated carbon. Rhazya stricta Decne. (Apocynaceae) is a small glabrous, erect herb that grows in deserts of South Asia and the Middle East Countries (Gilani et al. 2007). The aim of the present work was to achieve the optimal conditions for phenol removal by a novel activated carbon prepared from $R$. stricta leaves using factorial experimental design.

\section{Materials and methods}

Adsorbent preparation and characterization

Rhazya stricta leaves were collected from wadi Hermela, central Saudi Arabia (GPS location: $25^{\circ} 02^{\prime} 46.7^{\prime \prime} \mathrm{E}$ ). The leaves were washed several times with distilled water to remove any adherent dust. After that, they were air dried until constant weight. The dried leaves were then grinded to a fine powder. An aqueous solution of $\mathrm{H}_{2} \mathrm{SO}_{4}$ at the concentration of $25 \%$ was prepared. The powdered leaves of $R$. stricta $(250 \mathrm{~g})$ were soaked in the aqueous solution of $\mathrm{H}_{2} \mathrm{SO}_{4}(1,000 \mathrm{ml})$ for 5 days. The mixture was separated by filtration and the resultant product was washed several times until clearness and neutral $\mathrm{pH}$. The resulting product was then oven dried at $100{ }^{\circ} \mathrm{C}$ for $24 \mathrm{~h}$, then transferred to a muffle furnace and burnt at $600{ }^{\circ} \mathrm{C}$ for $2 \mathrm{~h}$. The weight loss during carbonization was about $85 \%$. The prepared chemically activated carbon was collected and stored in a desiccator until its use in the adsorption experiments.

The solution $\mathrm{pH}$ was adjusted at the beginning of each experiment using a solution of $0.5 \mathrm{M} \mathrm{HCl}$ and/or $\mathrm{NaOH}$ and the $\mathrm{pH}$ value was recorded using a THERMO Scientific ORION pH meter.

FTIR spectrum of the activated carbon prepared from $R$. stricta leaves was recorded using Thermo Nicolet Avatar 370 FTIR Spectrometer and the SEM imaging of the activated carbon was obtained using a Quanta 250-FEI scanning electron microscope.

\section{Adsorption experiment}

To optimize the adsorption of phenol by $R$. stricta activated carbon, a $2^{3}$ factorial design was employed. Three factors at two levels were chosen to study their effects on the removal of phenol by $R$. stricta activated carbon. The chosen factors were temperature $(T)$, solution $\mathrm{pH}(\mathrm{pH})$ and adsorbent weight $(X)$. The other experimental factors such as the initial phenol concentration $(100 \mathrm{mg} / \mathrm{l})$, speed of agitation $(100 \mathrm{rpm})$ and agitation time $(4 \mathrm{~h})$ were kept constant. The temperature, $\mathrm{pH}$ and adsorbent weight employed are shown in Table 1. The lower and upper levels of $\mathrm{pH}$ were chosen based on previously reported studies (Badr 2007; Rathinam et al. 2011).

At the beginning of each experimental run, $50 \mathrm{ml}$ of phenol solution was mixed with the adsorbent in a conical flask and the flasks were agitated on a shaking water bath at the required temperature. After the predetermined equilibrium time $(4 \mathrm{~h})$, the adsorbent was separated from the solutions by filtration and the remaining phenol concentration was determined by measuring its absorbance at $270 \mathrm{~nm}$ (Ioannou and Simitzis 2009) using a UV-Vis Spectrophotometer Double Beam Model UVD-3500. The phenol removal percentage $(R \%)$ was calculated as

Table 1 High and low level factors employed in the $2^{3}$ factorial design

\begin{tabular}{lll}
\hline Factor & Factor level \\
\cline { 2 - 3 } & Low level & High level \\
\hline Temperature $\left({ }^{\circ} \mathrm{C}\right)$ & 25 & 45 \\
Adsorbent weight $(\mathrm{g} / \mathrm{l})$ & 0.5 & 5 \\
$\mathrm{pH}$ & 3 & 9 \\
\hline
\end{tabular}


Fig. 1 FTIR spectrum of $R$. stricta leaves activated carbon

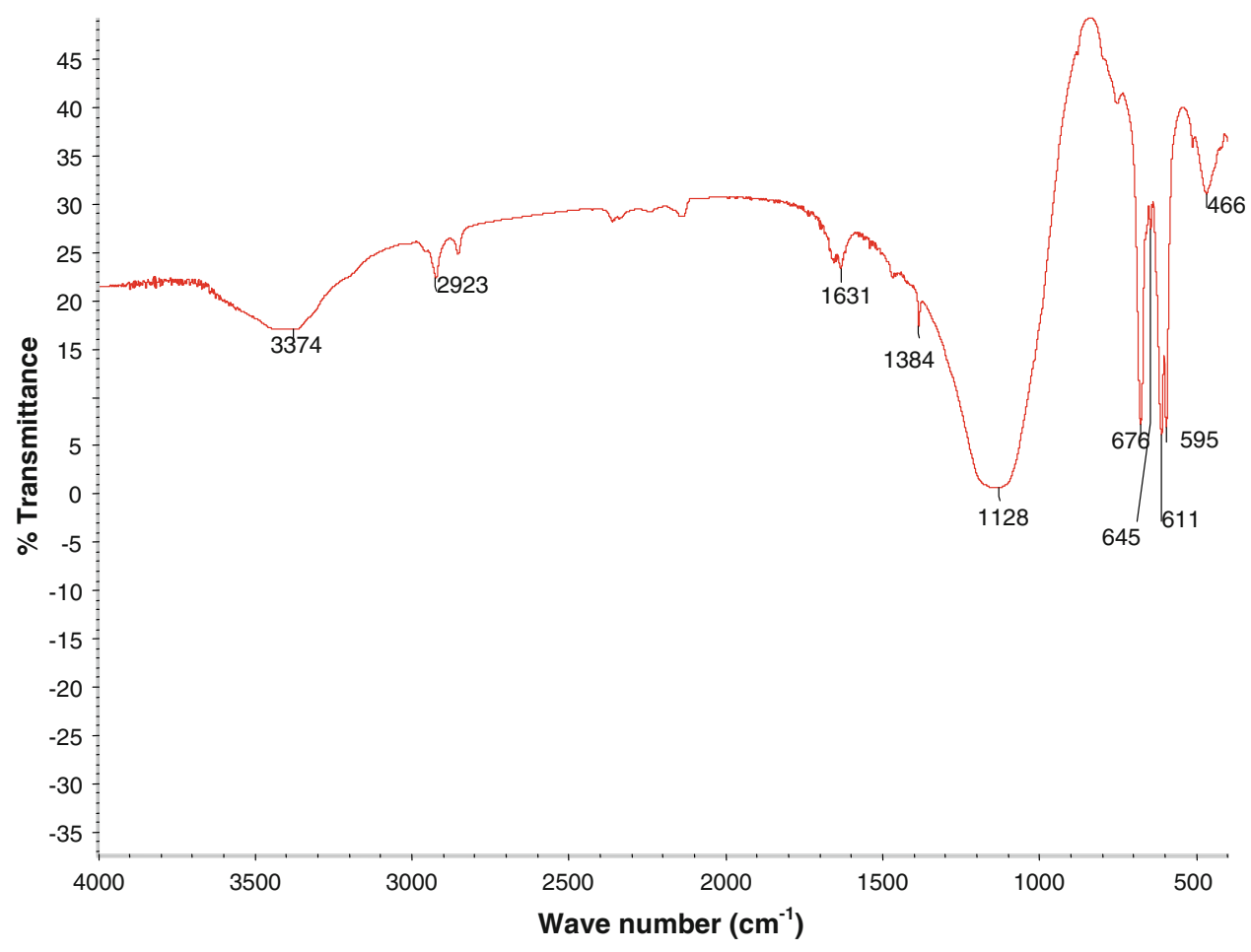

$R \%=\left(C_{\mathrm{i}}-C_{\mathrm{f}} / C_{\mathrm{i}}\right) \times 100$; where $C_{\mathrm{i}}$ and $C_{\mathrm{f}}$ are initial and final concentrations of phenol, respectively. The experimental results were analyzed using the Minitab 15 software, and the main effects and interactions between factors were determined.

\section{Results and discussion}

\section{Adsorbent characterization}

To determine the surface functional groups of $R$. stricta activated carbon, its FTIR spectrum was obtained as shown in Fig. 1. The spectrum revealed the presence of a number of characteristic bands in the range of $400-4,000 \mathrm{~cm}^{-1}$. A broad band at $3,374 \mathrm{~cm}^{-1}$ was assigned to $\mathrm{OH}$ stretching vibration, and may be also the characteristic peak of carbonyl and phenolic hydroxyl groups or adsorbed water (Huang et al. 2012). A weak peak at $2,923 \mathrm{~cm}^{-1}$ was ascribed to aliphatic group stretching vibration, and according to Huang et al. (2012) the low intensity of this peak is due to the decrease in aliphaticity in the activated carbon by increasing temperature. The band observed at $1,631 \mathrm{~cm}^{-1}$ was assigned to carbonyl $\mathrm{C}-\mathrm{O}$ present in carbonyls, ketones, aldehydes or ester groups and to $\mathrm{C}-\mathrm{C}$ present in olefinic vibrations in aromatic region (Virote et al. 2005; Apaydın-Varol and Pütün 2012). The band at $1,128 \mathrm{~cm}^{-1}$ is indicative of the $\mathrm{C}=\mathrm{O}$ and $-\mathrm{CO}$ stretching vibrations which indicate the existence of carbonyl containing groups (Huang et al. 2012). The bands around

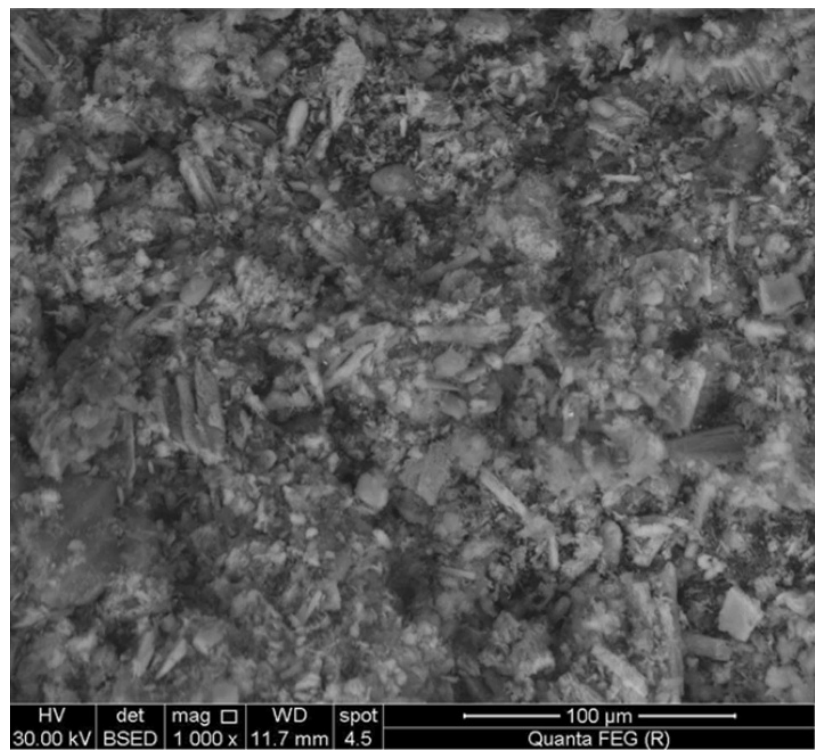

Fig. 2 SEM micrograph of $R$. stricta leaves activated carbon $(\times 1,000)$

$600 \mathrm{~cm}^{-1}$ was attributed to normal vibration modes of $\mathrm{SO}_{2}$ tetrahedral configuration (Olivares-Marín et al. 2012).

The surface morphology of $R$. stricta activated carbon as obtained by scanning electron microscopy is given in Fig. 2. The adsorbent surface contains particles of different sizes and different shapes indicating that the external surface of the activated carbon is heterogeneous. 
Table 2 Removal percentages (\%) of phenol by $R$. stricta activated carbon

\begin{tabular}{|c|c|c|c|c|c|}
\hline \multicolumn{3}{|c|}{ Factors } & \multicolumn{3}{|c|}{ Removal of phenol (\%) } \\
\hline$T$ & $X$ & $\mathrm{pH}$ & Trial (1) & Trial (2) & Average $(\%)$ \\
\hline-1 & -1 & -1 & 69.8 & 69.8 & 69.9 \\
\hline-1 & -1 & 1 & 73.2 & 73.3 & 73.2 \\
\hline-1 & 1 & -1 & 80.2 & 80.1 & 80.2 \\
\hline-1 & 1 & 1 & 79.1 & 78.7 & 78.9 \\
\hline 1 & 1 & 1 & 75.5 & 75.5 & 75.5 \\
\hline 1 & 1 & -1 & 84.4 & 82.0 & 83.2 \\
\hline 1 & -1 & -1 & 87.9 & 82.6 & 85.2 \\
\hline 1 & -1 & 1 & 75.0 & 74.4 & 74.7 \\
\hline
\end{tabular}

\section{Adsorption study}

All possible combinations of variables were used, and a matrix was established according to their high and low levels, represented by +1 and -1 , respectively (Hegazy et al. 2011). Table 2 gives the design matrix of coded values for the studied factors and the response in terms of phenol removal percentage.

The results of phenol removal using $R$. stricta activated carbon were analyzed using the software MINITAB 15 for windows. The factors affecting the removal of phenol by adsorption onto $R$. stricta activated carbon were evaluated using factorial plots including main effect, interaction effect, the Pareto chart and normal probability plots. Analysis of variance (ANOVA) and $P$ value significant levels were used to check the significance of the studied effect on phenol removal percentage.

\section{Analysis of variance (ANOVA)}

The main effects of factors $(T, X$ and $\mathrm{pH})$ and the interaction between factors $(T \cdot X, T \cdot \mathrm{pH}, X \cdot \mathrm{pH}$ and $T \cdot X \cdot \mathrm{pH})$ were determined. The effect of a factor is defined as the change in response produced by the change in level of that factor. This is frequently called a main effect as it refers to the primary factor of interest in the experiment (Rathinam et al. 2011).

Table 3 displays the main factors' effect, factors' interaction effect, coefficients of the model, standard deviation of each coefficient and the probability as well as Student's $t$ test values for each effect for the full $2^{3}$ factorial design. The significance of the regression coefficients was determined by applying a Student's $t$ test (Bingol et al. 2010). The results showed that all factors' effects were significant with $95 \%$ confidence level, with the exception of the interaction effect X.pH $(P=0.563)$. The $R^{2}$ statistic indicated that the first-order model explained $95.61 \%$ of the variability of phenol removal percentage. The model
Table 3 Estimated effects and coefficients for \% removal (coded units)

\begin{tabular}{lrrlrl}
\hline Term & Effect & Coefficient & $\begin{array}{l}\text { Standard error } \\
\text { coefficient }\end{array}$ & \multicolumn{1}{l}{$T$} & $P$ \\
\hline & & 77.596 & 0.3689 & 210.34 & 0.000 \\
$T$ & 4.156 & 2.078 & 0.3689 & 5.63 & 0.000 \\
$X$ & 3.674 & 1.837 & 0.3689 & 4.98 & 0.001 \\
$\mathrm{pH}$ & -4.024 & -2.012 & 0.3689 & -5.45 & 0.001 \\
$T \cdot X$ & -4.302 & -2.151 & 0.3689 & -5.83 & 0.000 \\
$T \cdot \mathrm{pH}$ & -5.076 & -2.538 & 0.3689 & -6.88 & 0.000 \\
$X \cdot \mathrm{pH}$ & -0.446 & -0.223 & 0.3689 & -0.60 & 0.563 \\
$T \cdot \mathrm{X} \cdot \mathrm{pH}$ & 1.863 & 0.931 & 0.3689 & 2.52 & 0.036 \\
\hline$S=1.47564$ &
\end{tabular}

$S=1.47564, R^{2}=95.61 \%, R^{2}$ (adjusted) $=91.77 \%$

also presented an adjusted square correlation coefficient $R^{2}$ (adjusted) of $91.77 \%$, fitting the statistical model quite well.

The codified mathematical model employed for the $2^{3}$ factorial design is given by (Abdel-Ghani et al. 2009):

$$
\begin{aligned}
\mathrm{R}= & A_{\mathrm{o}}+A_{1} \mathrm{~T}+A_{2} \mathrm{X}+A_{3} \mathrm{pH}+A_{4} \mathrm{TX}+A_{5} \mathrm{TpH} \\
& +A_{6} \mathrm{XpH}+A_{7} \mathrm{TXpH}
\end{aligned}
$$

where $A_{\mathrm{o}}$ represents the global mean and $A_{\mathrm{i}}$ the other regression coefficients.

Substituting the coefficients $A_{\mathrm{i}}$ in Eq. (1) by their corresponding values from Table 3 , phenol removal by $R$. stricta activated carbon could be expressed as:

$$
\begin{aligned}
\mathrm{R}(\mathrm{phenol})= & 77.596+2.078 \mathrm{~T}+1.837 \mathrm{X}-2.012 \mathrm{pH} \\
& -2.151 \mathrm{~T} \cdot \mathrm{X}-2.538 \mathrm{~T} \cdot \mathrm{pH}-0.223 \mathrm{X} \\
& \cdot \mathrm{pH}+0.931 \mathrm{~T} \cdot \mathrm{X} \cdot \mathrm{pH}
\end{aligned}
$$

According to Rathinam et al. (2011), when the effect of a factor is positive, removal efficiency increases as the factor is changed from low to high levels. In contrast, if the effects are negative, a reduction in removal efficiency occurs for the high level of the same factor. Thus, it can be concluded from Eq. (2) that a change in the temperature from low to high level results in $2.078 \%$ increase in the phenol removal efficiency. Also, when the adsorbent dosage was increased from low to high value, a $1.837 \%$ increase in the phenol removal was observed. On the other hand, an increase in $\mathrm{pH}$ from low to high level resulted in $2.012 \%$ decrease in phenol removal.

The increased phenol removal by adsorption onto $R$. stricta activated carbon observed as the temperature was raised from 25 to $45{ }^{\circ} \mathrm{C}$ can be explained on the basis of hydrogen bonding. According to Nayak and Singh (2007), there exists extensive hydrogen bonding between the phenol molecule and water in aqueous solution of phenol resulting in appreciable solubility. This hydrogen bonding 
gets broken at higher temperatures and, this would cause phenol to be less soluble and, therefore, exhibit a higher tendency to go to the adsorbent surface and adsorbed rather than remaining in solution.

Regarding the effect of $\mathrm{pH}$ on phenol removal by adsorption onto $R$. stricta activated carbon, it has been generally known that the solution $\mathrm{pH}$ influences the degree of the ionization of phenolic compounds and surface charge of adsorbents and thereby controls the adsorption processes (Park et al. 2010). Especially, this phenomenon is noted in the case of phenol adsorption on AC (Thinakaran et al. 2008); (Hameed and Rahman 2008). In the present study, there was a slight reduction in the phenol removal percentage with increasing initial $\mathrm{pH}$ from 3 to 9. According to Hameed and Rahman (2008), phenol adsorption decreases at high $\mathrm{pH}$ values due to ionization of adsorbate molecules. The reason could be also the electrostatic repulsions between the negative surface charge and the phenolate-phenolate anions in solution (MorenoCastilla 2004). While at acidic $\mathrm{pH}$, the percentage removal was higher because phenol was undissociated and the dispersion interaction predominated (Hameed and Rahman 2008).

The increase in adsorbent weight from 0.5 to $5 \mathrm{~g} / \mathrm{l}$ resulted in an increase in phenol removal percentage due to the greater availability of the exchangeable sites or surface area of the adsorbent (Kilic et al. 2011).

After estimating the factors' main effects, the determination of the significant factors affecting the removal efficiency was performed by ANOVA. Table 4 shows the sum of squares being used to estimate the factors' effect and the $F$ ratios, which are defined as the ratio of the respective mean-square-effect to the mean-square-error (Bingol et al. 2010). From the $P$ value, defined as the lowest level of significance leading to the rejection of the null hypothesis (Abdel-Ghani et al. 2009), it can be seen that the main factors, two-way interactions and three-way interactions were all significant at $5 \%$ of probability level $(P<0.05)$.

Table 4 Analysis of variance for \% removal (coded units)

\begin{tabular}{lrrrrrl}
\hline Source & $d f$ & Seq SS & Adj SS & Adj MS & \multicolumn{1}{l}{$F$} & \multicolumn{1}{l}{$P$} \\
\hline Main effects & 3 & 187.84 & 187.84 & 62.614 & 28.75 & 0.000 \\
2-way interactions & 3 & 177.88 & 177.88 & 59.293 & 27.23 & 0.000 \\
3-way interactions & 1 & 13.88 & 13.88 & 13.877 & 6.37 & 0.036 \\
Residual error & 8 & 17.42 & 17.42 & 2.178 & & \\
Pure error & 8 & 17.42 & 17.42 & 2.178 & & \\
Total & 15 & 397.02 & & & & \\
\hline
\end{tabular}

$d f$ degree of freedom, Seq SS sequential sum of squares, Adj SS adjusted sum of squares, Adj $M S$ adjusted mean sum of squares, $F$ factor $F, P$ probability
The main effects

The mean changes that occur in the response (\% of phenol removal) when the levels of each of the main factors were changed from low to high level are presented in Fig. 3. The statistical significance of a factor is directly related to the length of the vertical line (Palanikumar and Davim 2009). It has to be also noted that the larger the vertical line, the larger the change in the response when changing the main factor from level -1 to level +1 (Bingol et al. 2010). Thus, from Fig. 3, it can be concluded that the temperature and adsorbent weight have positive effect on phenol removal by $R$. stricta activated carbon, when both factors are changed from low to high and the opposite is true for the initial solution pH. From the length of the vertical lines, it can be noticed that the adsorbent weight had the lowest effect on phenol removal.

The interaction effects

An interaction is effective when the change in the response from low to high levels of a factor is dependent on the level of a second factor, i.e., when the lines do not run parallel (Mathialagan and Viraraghavan 2005). Figure 4 shows the interaction plots for phenol removal using $R$. stricta leaves activated carbon. It can be seen that there is a strong interactional effect between adsorbent dosage and temperature as well as between temperature and $\mathrm{pH}$. Alternatively, the interaction between the adsorbent dosage and $\mathrm{pH}$ was not effective.

As can be seen from Fig. 4, when the temperature is increased from 25 to $45^{\circ} \mathrm{C}$, the phenol removal efficiency increased from 69.85 to $85.24 \%$ at an adsorbent dosage $0.5 \mathrm{~g} / \mathrm{l}$ and from 80.13 to $83.20 \%$ at an adsorbent dosage of $10 \mathrm{~g} / \mathrm{L}$. This result suggests that the effect of temperature is high when the dosage is low but at higher dosage, effect of temperature is small. Similarly, when the temperature is increased from 25 to $45^{\circ} \mathrm{C}$, the phenol removal efficiency increased from 69.85 to $85.24 \%$ at $\mathrm{pH} 3.0$ and from 73.21 to $74.72 \%$ at $\mathrm{pH} 9.0$. Thus, it can be concluded that the effect of temperature is more pronounced at low $\mathrm{pH}$ than at high $\mathrm{pH}$.

\section{The Pareto chart}

The relative importance of the main effects and their interactions is graphically presented by the Pareto chart given in Fig. 5. The vertical line in Fig. 5 indicates minimum statistically significant effect magnitude for a $95 \%$ confidence level. It was observed that for a $95 \%$ confidence level and eight freedom degrees, the $t$ value was equal to 2.306. This value is in agreement with the values 
Fig. 3 Main effects plot for \% phenol removal using $R$. stricta leaves activated carbon
Effects Plot for \% Removal

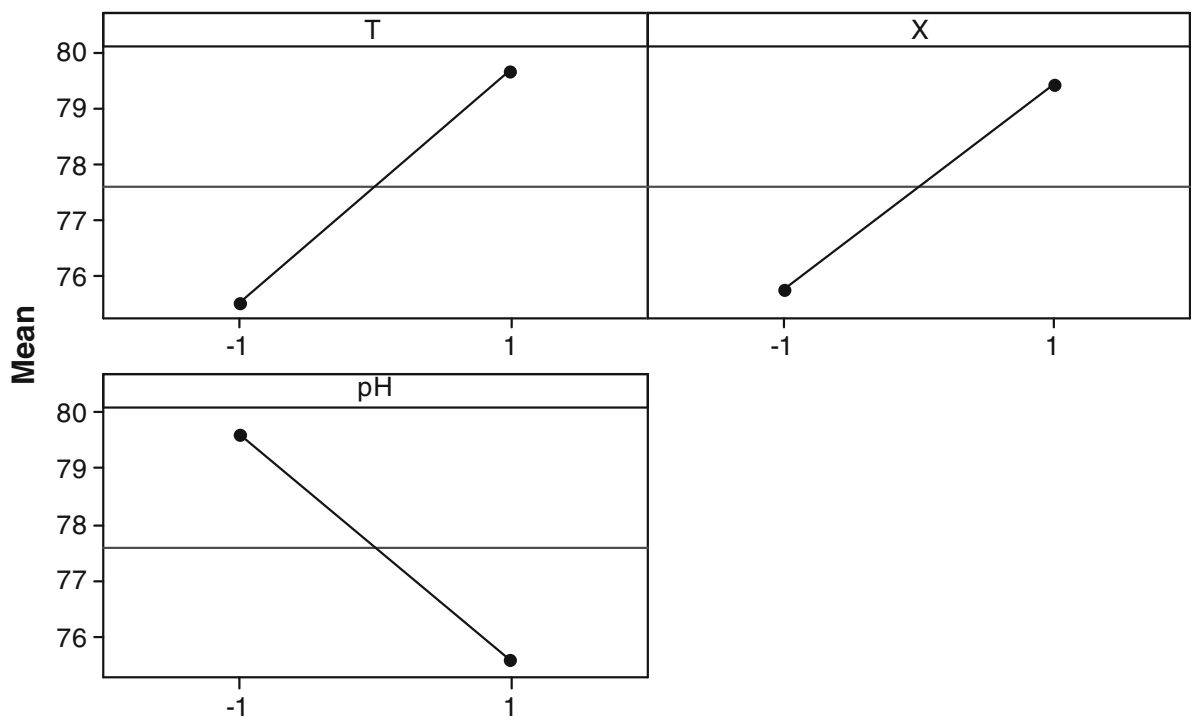

interaction

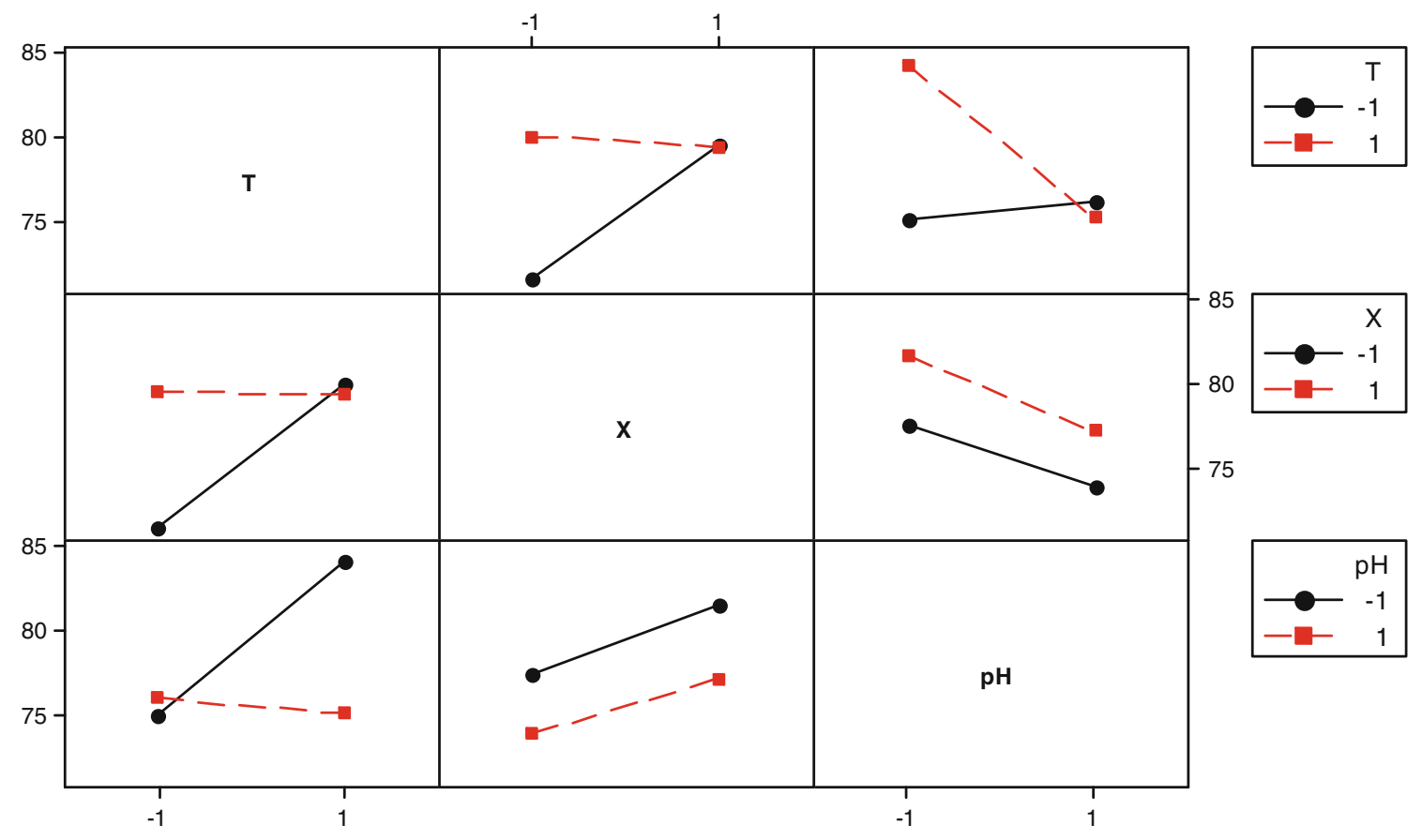

Fig. 4 Interaction effect plot for \% phenol removal using $R$. stricta leaves activated carbon

previously reported in the literature (Carmona et al. 2005; Abdel-Ghani et al. 2009; Hegazy et al. 2011). Values shown in horizontal columns are Student's $t$ test values for each effect. All the values presenting an absolute value higher than 2.306, which are located right of the vertical line, are significant. Analyzing the Pareto chart, it can be seen that the interaction between the temperature and $\mathrm{pH}$
$(T \cdot \mathrm{pH})$ had the greatest effect on the removal percentage of phenol by $R$. stricta activated carbon. The second interaction affecting the phenol removal percentage was the interaction between the temperature and adsorbent dose $(T \cdot X)$ followed by the temperature $(T), \mathrm{pH}$ of solution $(\mathrm{pH})$, adsorbent dose $(X)$ and finally the interaction among the three main factors $(T \cdot X \cdot \mathrm{pH})$. 
Fig. 5 Pareto chart of statistical effects on the removal of phenol at $P=0.05$

Fig. 6 Normal probability plot of standardized effects at $P=0.05$
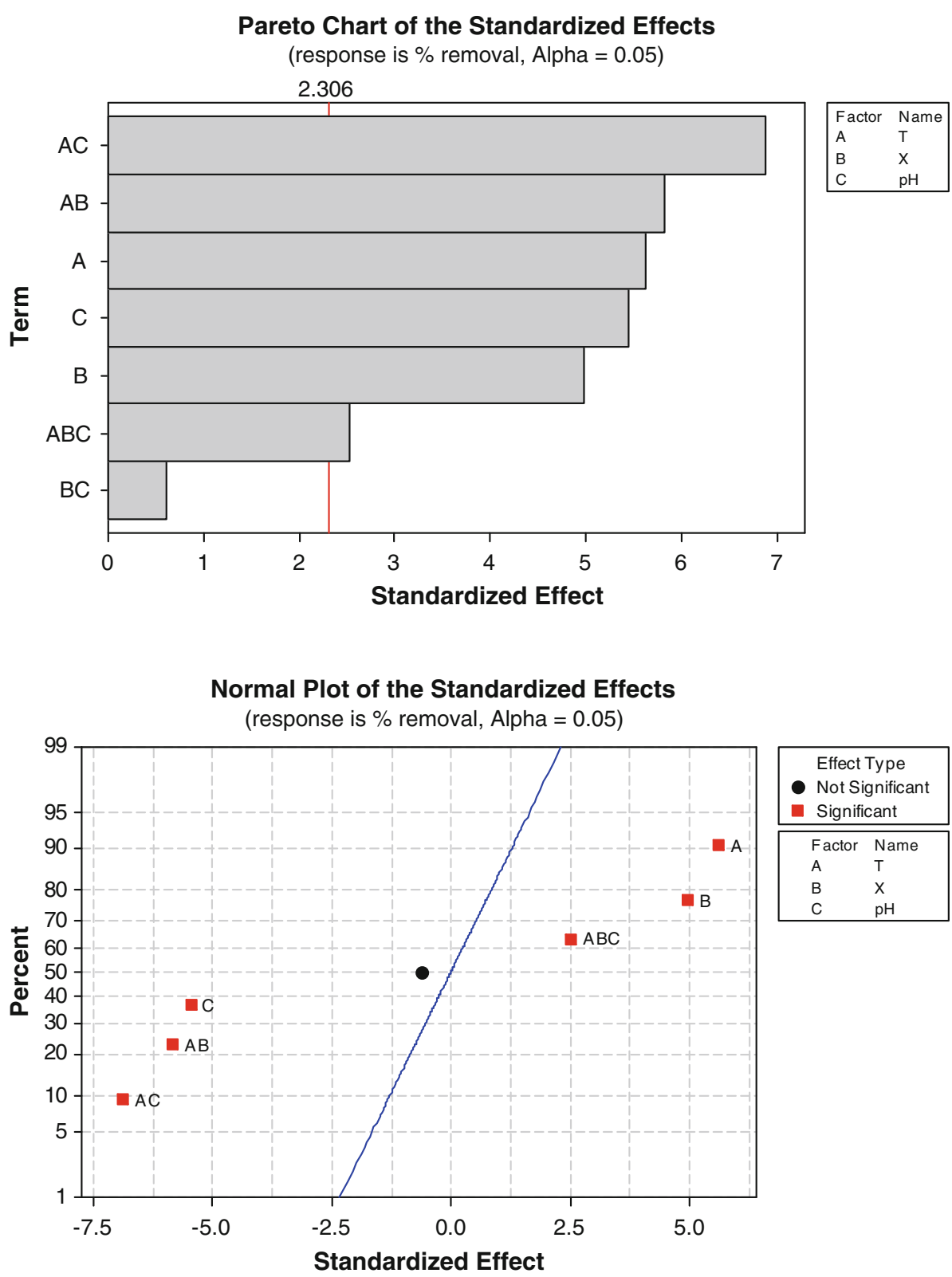

The normal probability

To better evaluate each factor and its interaction, the normal probability plot of standardized effects is presented in Fig. 6. According to Bingol et al. (2010), a normal probability plot is used to identify the "real" effects from those obtained by chance. One point on the plot is assigned to each effect. According to the normal probability plots, the points which are close to a line fitted to the middle group of points represent those estimated factors that do not demonstrate any significant effect on the response variables. Points far away from the line likely represent the "real" factor effects (Brasil et al. 2006; Palanikumar and Davim 2009). The plot (Fig. 6) is divided into two regions: the region with percentage below 50, where the factors and their interactions presented negative coefficients $(\mathrm{pH}$, $T \cdot X$ and $X \cdot \mathrm{pH}$ ), and the region with percentage above 50 , where the factors presented positive coefficients $(T, X$ and $T \cdot X \cdot \mathrm{pH})$. It can also be observed that the main factors $(T$, $X$ and $\mathrm{pH})$ as well as their interactions $(T \cdot X, X \cdot \mathrm{pH}$ and $T \cdot X \cdot \mathrm{pH})$ are far away from the straight line and are therefore considered to be "real". The order in which the main factors and their interaction affect the phenol removal percentage by $R$. stricta carbon is as follows: $T \cdot \mathrm{pH}>T \cdot X>$ $T>\mathrm{pH}>X>T \cdot X \cdot \mathrm{pH}$. This order is computed based on the distance of each "square" in Fig. 6 from the straight line and considering that when the factor's point lies farthest from the line, this means the factor's effect is higher (Bingol 


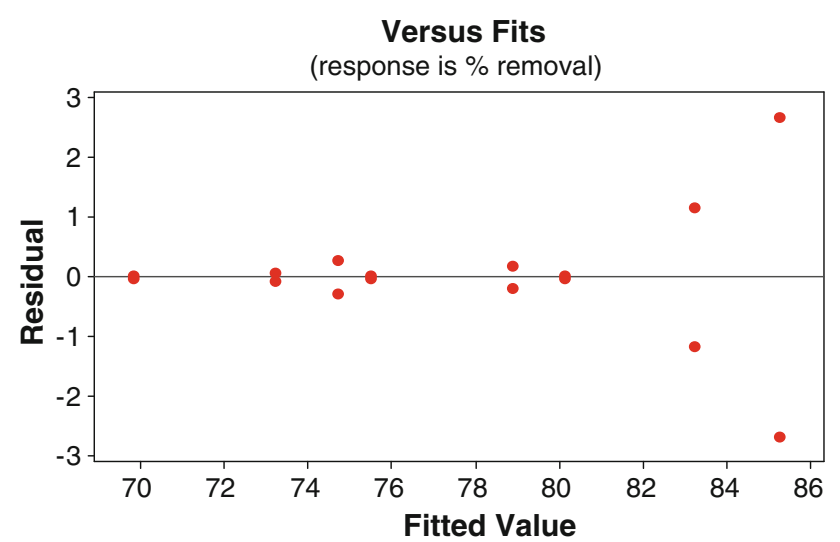

Fig. 7 Percentage phenol removal (predicted) vs. residual

et al. 2010). These results confirm the analysis of Pareto chart (Fig. 5) and the values of Table 3.

Residual analysis

The adequacy of the model was also evaluated by the residuals (difference between the experimental and the predicted values). Residuals are thought as elements of variation unexplained by the fitted model and then it is expected that they occur according to a normal distribution (Meski et al. 2011). The plot of percentage phenol removal predicted versus residual (Fig. 7) did not show any outliers, all the points were found to fall in the range of +3 to -3 , which indicated that the model presents a minimal deviation of the fitted value from the observed (Carmona et al. 2005; Rathinam et al. 2011).

\section{Comparison of maximum phenol removal}

The maximum removal of phenol by adsorption onto $R$. stricta activated carbon at the optimum conditions was $85 \%$. In the previous studies reported in the literature, the removal percentage of phenol was found to be $87.6 \%$ on activated carbon prepared from tobacco residues (Kilic et al. 2011); $95.31 \%$ on activated carbon prepared from seaweed (Rathinam et al. 2011) and ranged from 79 to $98 \%$ onto activated carbons prepared from African beech wood sawdust (Abdel-Ghani et al. 2013).

\section{Conclusion}

The preparation of a novel activated carbon from $R$. stricta leaves as a cheap and locally available material was successfully achieved. To determine the effects of various operating conditions ( $\mathrm{pH}$, adsorbent dose and temperature) and their interactions on the adsorption of phenol by R. stricta activated carbon, a full $2^{3}$ factorial design was performed. ANOVA, $t$ test and $F$ test showed that the three tested variables $(T, X$ and $\mathrm{pH})$ as well as their interactions were statistically significant except the interaction $(X \cdot \mathrm{pH})$. The prepared activated carbon showed high adsorption efficiency for the removal of phenol from aqueous solution. The present research highlights the use of a cheap activated carbon prepared from $R$. stricta, a locally grown plant for wastewater decontamination.

Acknowledgments The authors thank the deanship of scientific research at King Saud University for supporting the work through the research group project No. RGP-VPP-175.

Open Access This article is distributed under the terms of the Creative Commons Attribution License which permits any use, distribution, and reproduction in any medium, provided the original author(s) and the source are credited.

\section{References}

Abdel-Ghani NT, Hegazy AK, El-Chaghaby GA, Lima EC (2009) Factorial experimental design for biosorption of iron and zinc using Typha domingensis phytomass. Desalination 249(1): 343-347. doi:10.1016/j.desal.2009.02.065

Abdel-Ghani NT, El-Chaghaby GA, Helal FS (2013) Preparation, characterization and phenol adsorption capacity of activated carbons from African beech wood sawdust. Environ Eng Manag $\mathrm{J}$ (in press) http://omicron.ch.tuiasi.ro/EEMJ/

Apaydın-Varol E, Pütün AE (2012) Preparation and characterization of pyrolytic chars from different biomass samples. J Anal Appl Pyrolysis 98:29-36. doi:10.1016/j.jaap.2012.07.001

Badr N (2007) Statistical design of experiments as a tool for optimizing the biosorption of $\mathrm{Pb}^{2+}$ and $\mathrm{Cd}^{2+}$ on Eichhornia Crassipes (Mart.) Solms. Glob J Environ Res 1(2):33-42. http:// www.idosi.org/gjer/gjer1\%282\%2907/1.pdf

Bingol D, Tekin N, Alkan M (2010) Brilliant Yellow dye adsorption onto sepiolite using a full factorial design. Appl Clay Sci 50(3):315-321. doi:10.1016/j.clay.2010.08.015

Boonamnuayvitaya V, Sae-ung S, Tanthapanichakoon W (2005) Preparation of activated carbons from coffee residue for the adsorption of formaldehyde. Sep Purif Technol 42(2):159-168. doi:10.1016/j.seppur.2004.07.007

Brasil JL, Ev RR, Milcharek C, Martins LC, Pavan FA, dos Santos AA Jr, Dias SLP, Dupont J, Noreña CPZ, Lima EC (2006) Statistical design of experiments as a tool for optimizing the batch conditions to $\mathrm{Cr}(\mathrm{VI})$ biosorption on Araucaria angustifolia wastes. J Hazard Mater B133:143-153. doi:10.1016/j.jhazmat.2005.10.002

Carmona MER, Da Silva MAP, Ferreira Leite SG (2005) Biosorption of chromium using factorial experimental design. Process Biochem 40(40):779-788. doi:10.1016/j.procbio.2004.02.024

Foo KY, Hameed BH (2010) Insights into the modeling of adsorption isotherm systems. Chem Eng J 156(1):2-10. doi:10.1016/j.cej. 2009.09.013

Gerçel Ö, Özcan A, Özcan AS, Gerçel HF (2007) Preparation of activated carbon from a renewable bio-plant of Euphorbia rigida by $\mathrm{H}_{2} \mathrm{SO}_{4}$ activation and its adsorption behavior in aqueous solutions. Appl Surf Sci 253(11):4843-4852. doi:10.1016/j. apsusc. 2006.10 .053

Gilani SA, Kikuchi A, Shinwari ZK, Khattak ZI, Watanabe KN (2007) Phytochemical, pharmacological and ethnobotanical studies of Rhazya stricta Decne. Phytother Res 21(4):301-307. doi:10.1002/ptr 
Hameed BH, Rahman AA (2008) Removal of phenol from aqueous solutions by adsorption onto activated carbon prepared from biomass material. J Hazard Mater 160(2-3):576-581. doi:10. 1016/j.jhazmat.2008.03.028

Hameed BH, Salman JM, Ahmad AL (2009) Adsorption isotherm and kinetic modeling of 2,4-D pesticide on activated carbon derived from date stones. J Hazard Mater 163(1):121-126. doi:10.1016/j. jhazmat.2008.06.069

Hegazy AK, Abdel-Ghani NT, El-Chaghaby GA (2011) Factorial design for optimizing the removal of aluminium from aqueous solutions by adsorption on Typha domingensis phytomass. Desalination Water Treat 36(1-3):392-399. doi:10.5004/dwt 2011.2421

Huang L, Kong J, Wang W, Zhang C, Niu S, Gao B (2012) Study on $\mathrm{Fe}(\mathrm{III})$ and $\mathrm{Mn}(\mathrm{II})$ modified activated carbons derived from Zizania latifolia to removal basic fuchsin. Desalination 286:268-276. doi:10.1016/j.desal.2011.11.034

Ioannou Z, Simitzis J (2009) Adsorption kinetics of phenol and 3-nitrophenol from aqueous solutions on conventional and novel carbons. J Hazard Mater 171:954-964. doi:10.1016/j.jhazmat. 2009.06.098

Kilic M, Apaydin-Varol E, Pütün AE (2011) Adsorptive removal of phenol from aqueous solutions on activated carbon prepared from tobacco residues: equilibrium, kinetics and thermodynamics. J Hazard Mater 189(1-2):397-403. doi:10.1016/j.jhazmat. 2011.02.051

Li Y, Du Q, Wang X, Zhang P, Wang D, Wang Z, Xia Y (2010) Removal of lead from aqueous solution by activated carbon prepared from Enteromorpha prolifera by zinc chloride activation. J Hazard Mater 183(1-3):583-589. doi:10.1016/j.jhazmat. 2010.07.063

Lin S-H, Juang R-S (2009) Adsorption of phenol and its derivatives from water using synthetic resins and low-cost natural adsorbents: a review. J Environ Manag 90(3):1336-1349. doi:10. 1016/j.jenvman.2008.09.003

Mathialagan T, Viraraghavan T (2005) Biosorption of pentachlorophenol by fungal biomass from aqueous solutions: a factorial design analysis. Environ Technol 26(5):571-579. doi:10.1080/ 09593332608618542

Meski S, Ziani S, Khireddine H, Boudboub S, Zaidi S (2011) Factorial design analysis for sorption of zinc on hydroxyapatite. J Hazard Mater 186:1007-1017. doi:10.1016/j.jhazmat.2010.11. 087

Mohanty K, Das D, Biswas MN (2005) Adsorption of phenol from aqueous solutions using activated carbons prepared from Tectona grandis sawdust by $\mathrm{ZnCl} 2$ activation. Chem Eng J 115(1-2):121-131. doi:10.1016/j.cej.2005.09.016

Momčilović M, Purenović M, Bojić A, Zarubica A, Ranđelović M (2011) Removal of lead(II) ions from aqueous solutions by adsorption onto pine cone activated carbon. Desalination 276(1-3):53-59. doi:10.1016/j.desal.2011.03.013
Moreno-Castilla C (2004) Adsorption of organic molecules from aqueous solutions on carbon materials. Carbon 42(1):83-94. doi:10.1016/j.carbon.2003.09.022

Nayak PS, Singh BK (2007) Removal of phenol from aqueous solutions by sorption on low cost clay. Desalination 207(1-3):71-79. doi:10.1016/j.desal.2006.07.005

Olivares-Marín M, Fernández-González C, Macías-García A, GómezSerrano V (2012) Preparation of activated carbon from cherry stones by physical activation in air. Influence of the chemical carbonisation with $\mathrm{H}_{2} \mathrm{SO}_{4}$. J Anal Appl Pyrol 94:131-137. doi:10.1016/j.jaap.2011.11.019

Palanikumar K, Davim JP (2009) Assessment of some factors influencing tool wear on the machining of glass fibre-reinforced plastics by coated cemented carbide tools. J Mater Process Technol 209(1):511-519. doi:10.1016/j.jmatprotec.2008.02.020

Park K-H, Balathanigaimani MS, Shim W-G, Lee J-W, Moon H (2010) Adsorption characteristics of phenol on novel corn grainbased activated carbons. Microporous Mesoporous Mater. doi:10.1016/j.micromeso.2009.06.032

Poinern GEJ, Senanayake G, Shah N, Thi-Le XN, Parkinson GM, Fawcett D (2011) Adsorption of the aurocyanide, complex on granular activated carbons derived from macadamia nut shellsa preliminary study. Miner Eng 24(15):1694-1702. doi:10.1016/ j.mineng.2011.09.011

Rathinam A, Rao JR, Nair BU (2011) Adsorption of phenol onto activated carbon from seaweed: determination of the optimal experimental parameters using factorial design. J Taiwan Inst Chem Eng 42(6):952-956. doi:10.1016/j.jtice.2011.04.003

Subramanyam B, Das A (2009) Study of the adsorption of phenol by two soils based on kinetic and isotherm modeling analyses. Desalination 249(3):914-921. doi:10.1016/j.desal.2009.05.020

Thinakaran N, Baskaralingam P, Pulikesi M, Panneerselvam P, Sivanesan S (2008) Removal of Acid Violet 17 from aqueous solutions by adsorption onto activated carbon prepared from sunflower seed hull. J Hazard Mater 151(2-3):316-322. doi:10. 1016/j.jhazmat.2007.05.07

Tongpoothorn W, Sriuttha M, Homchan P, Chanthai S, Ruangviriyachai $C$ (2011) Preparation of activated carbon derived from Jatropha curcas fruit shell by simple thermo-chemical activation and characterization of their physico-chemical properties. Chem Eng Res Des 89(3):335-340. doi:10.1016/j.cherd.2010.06.012

Virote B, Srisuda S, Wiwut T (2005) Preparation of activated carbons from coffee residue for the adsorption of formaldehyde. Sep Purif Technol 42:159-168. doi:10.1016/j.seppur.2004.07.007

Zhang J, Shi Q, Zhang C, Xu J, Zhai B, Zhang B (2008) Adsorption of Neutral Red onto Mn-impregnated activated carbons prepared from Typha orientalis. Bioresour Technol 99(18):8974-8980. doi:10.1016/j.biortech.2008.05.018 